\title{
インターロッキング式橋脚の耐震性能抢よび 施工方法について
}

\author{
井ヶ瀬良則*1・野村謙二*2・黒岩俊之*3 ・宮城敏明*4
}

\begin{abstract}
概 要 インターロッキング型配筋を有する鉄筋コンクリート橋脚は，施工性，而震性に優れ，矩形断面を有する鉄筋 コンクリート橋脚の横拘束筋を合理化するのに有効である。本稿では, インターロッキング式橋脚の耐震性能および施工 方法について紹介する。

キーワード：インターロッキング式配筋，鉄筋コンクリート橋脚，耐震性能，施工方法，合理化
\end{abstract}

\section{1.はじめに}

平成 7 年兵庫県南部地震による被災の教訓から，鉄筋 コンクリート橋脚（以後, $\mathrm{RC}$ 橋脚）の横拘束の重要性 が再認識され，震災後，多くの耐震設計基準が改定され てきた。道路橋示方書 ${ }^{1)}$ では，中間帯鉄筋を帯鉄筋の配 置されるすべての断面に配筋するとともに，その間隔は， $1.0 \mathrm{~m}$ 以内とするように規定している。こうした配筋構 造は， RC 橋脚に十分なじん性能を確保するためには有 効であるが，断面によっては過密な配筋となり，鉄筋材 料費亡鉄筋労務工数の増加による経済性の低下を招くだ けでなく，コンクリートの締固め作業を困難にしている。 このような背景から，配筋構造を合理化することにより， 耐震性を確保しつつ， 経済的かつ効率的に $\mathrm{RC}$ 橋脚を構築する手法が望まれている。

矩形断面の横拘束を効果的に行う手法として，アメリ カなど，諸外国で採用されているインターロッキング 型式の配筋方法がある。本工法については，道路橋示方 書（平成 8 年 12 月）において紹介されてはいるものの, 具体的な設計方法に関しては示されていない。アメリカ

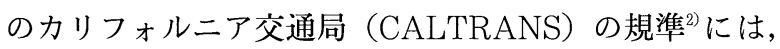
インターロッキング型配筋構造の橋脚 (以後, インター ロッキング式橋脚）の設計に関する記述があり，配筋方 法等に関する規定がなされている。しかしながら，日本 とアメリカでは，耐震設計法，構造細目等の違いがあり， 日本においてインターロッキング式橋脚を従来型の RC 橋脚の代替として採用するためには，実験等によって， 設計のための基礎データを得る必要があった。

\footnotetext{
＊1 いがせ・よしのり/日本道路公団 試験研究所 道路研究部 橋梁 研究室 主任 (正会員)

*2 のむら・けんじ/日本道路公団 東京建設局 建設第一部 構造技術 課 課長代理

*3 くろいわ・としゅき/東急建設(㑣) 技術研究所 土木研究室 研究 員（正会員）

*4 みやき・としあき/東急建設侏 技術研究所 土木研究室 室長（正 会員）
}

そこで筆者らは，インターロッキング型配筋による， $\mathrm{RC}$ 橋脚の配筋構造の合理化に関する研究を進めてき

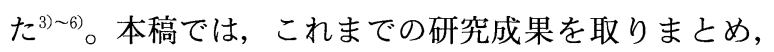
インターロッキング式橋脚の耐震性能について報告する。 また, 実施工を模擬して行った実大施工実験のうち, 効 率良く組立てることが出来たスパイラル筋による施工方 法について紹介する。

\section{2. インターロッキング型配筋構造}

従来型の配筋構造では, 十分な拘束効果を得るため, 帯鉄筋と帯鉄筋のはらみだしを抑える中間帯鉄筋を組み 合わせて配置している（図-1）。インターロッキング型 配筋構造とは, 従来のように矩形の帯鉄筋と中間帯鉄筋 とを併用する替わりに，円形フープ筋もしくは円形スパ イラル筋を部分的にラップさせて矩形断面（小判形断面） の横拘束筋とするものである（図-2）。

一般に円形フープ筋は，コンクリートの拘束効果が高 く, 主鉄筋の座屈防止にも有効であることから, 中間帯 鉄筋を配さずとも，十分な拘束効果が得られる場合が多 い。したがって, インターロッキング型式の配筋を矩形 断面に採用すれば，配筋の合理化が可能となる。たとえ ば表-1 に示すように矩形帯筋に中間帯鉄筋を併用する

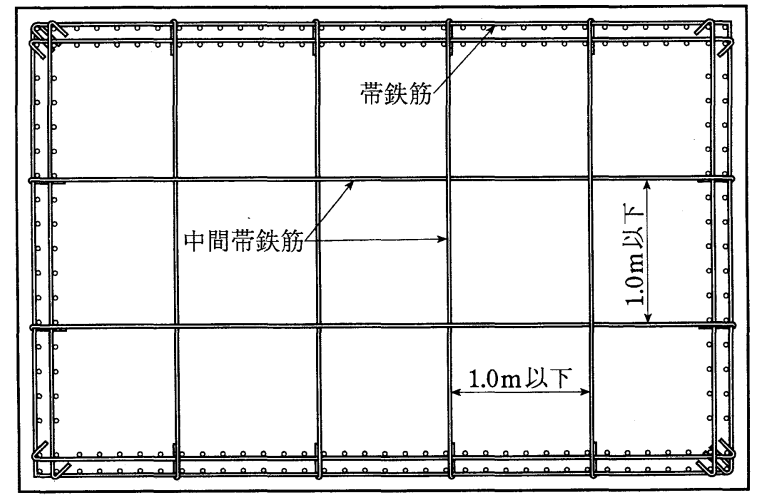

図-1＼cjkstart従来型の配筋構造の例 


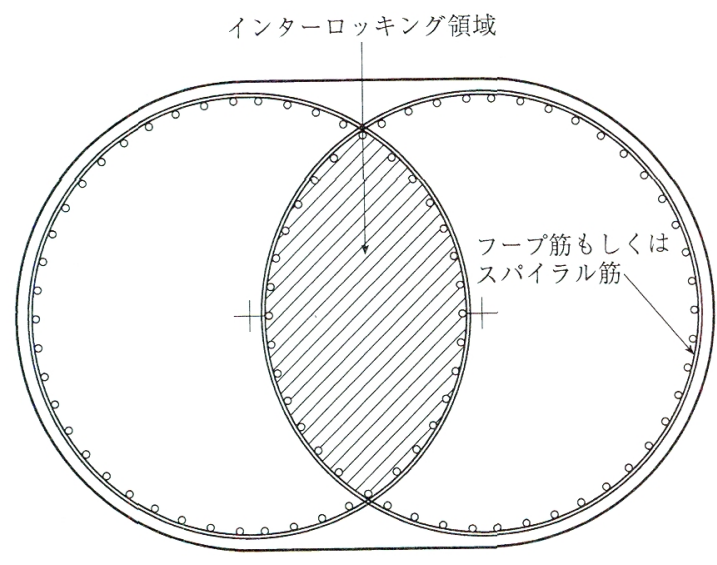

図-2 インターロッキング型配筋構造の例

場合に比べて帯鉄筋量を低減することができるだけでな く，スパイラル筋を用いた場合には，定着長やフックが 省略できることから，組立作業が大幅に簡略化されると 考えられる。

\section{3. 耐震性能確認実験}

\section{1 実験の目的}

インターロッキング式橋脚に関する実験は，これまで にも国内外でいくつか行われてきている ${ }^{7) \sim 11 。} 。$ そ多く は橋軸直角 (長辺) 万向を対象とし, 主に 2 組のスパイ ラル筋の中心間距離や，インターロッキング領域の主鉄 筋量の影響に着目したせん断耐力に関する研究である。 これらは主として，CALTRANS の設計基準で示され る，(1)隣り合うスパイラル筋の中心間距離をスパイラル 直径の 0.75 倍以下とすること，(2)インターロッキング 領域に最低 4 本の主鉄筋を配置すること（図-3）を検証 することを目的としている。一方，橋軸（短辺）方向に ついては，特に帯鉄筋量をパラメータとした実験デー夕 は少なく，変形性能に及ぼす帯鉄筋量の影響については， 十分な検討がなされているとはいえない。

このような現状を踏まえ，橋軸および橋軸直角方向に 対して帯鉄筋量を变えた試験体の実験を行い, 帯鉄筋量 の違いが橋脚の破壊モード，塑性変形能等に及ぼす影響 を調べ，設計のための基礎デー夕を得ることとした。

橋軸方向の実験においては, 従来型配筋構造の矩形橋 脚（以後, 従来型矩形橋脚）およびインターロッキング 式橋脚の正負交番載荷実験を行い, 雨者を比較すること
表-1 帯鉄筋施工数量の比較

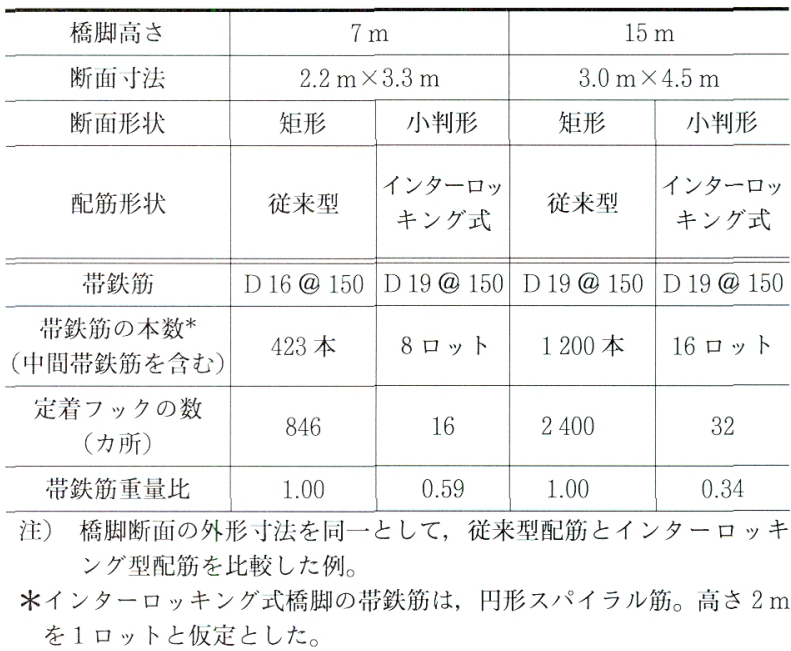

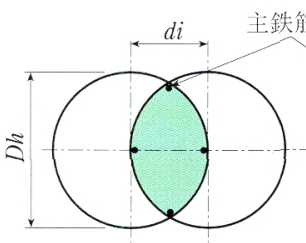

$d i / D h=0.5$

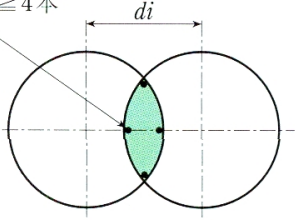

$d i / D h=0.75$
$(0.5) \leqq d i / D h \leqq 0.75$

ここに,

$d i$ : フープ筋の中心間距離

Dh: フープ筋の直径 (鉄筋の中心間距離)

図-3 CALTRANS の設計基準

によって，インターロッキング式橋脚の耐震性能を調べ た。

橋軸直角方向の実験は，日本で初めてインターロッキ ング式橋脚として建設された，中部横断自動車道富士川 橋下部工の耐震性能を確認することを目的とした実験で ある。写真-1 に富士川橋の配筋状況を，図-4 に断面図 を示す。本実験ではインターロッキング型フープ筋を有 する橋脚の耐震性能およびせん断耐力について検討した。

\section{2 試験体概要}

（1）橋軸方向試験体

試験体諸元および配筋図を表-2および図-5（a）に示 す。試験体は, 従来型矩形橋脚 1 体 (UNIT0) および インターロッキング式橋脚 3 体（UNIT 1，2，3）の計 4 体である。

Seismic Performance and Construction Method of Bridge Columns with Interlocking Spiral/Hoop Reinforcement

By Y. Igase, K. Nomura, T. Kuroiwa and T. Miyagi

Concrete Journal, Vol. 40, No. 2, pp. 37 46, Feb. 2002

Synopsis Interlocking spiral reinforcement is one of the rational reinforcing methods for rectangular column sections because of its easy construction and effective lateral confinement. In this paper, seismic performance and construction method of bridge columns with interlocking spiral/hoop reinforcement are reported.

Keywords: Interlocking spirals, Reinforced concrete pier, Seismic performance, construction method, Simplification 
UNIT0は，道路橋示方書に基づいて設計した標準的 な矩形断面橋脚の約 $1 / 5$ の諸元を有する模型で，その断 面は幅 $\times$ 高さ $=900 \times 600 \mathrm{~mm}$ である。帯鉄筋の定着は, 135 度フック（フック長は帯筋径の 6 倍）とした。 UNIT 1，2，3 の断面はこれと同外形寸法を有する小判形 とした。また，せ九断スパン比は 5.0 である。UNIT0 の主鉄筋比は，1.18\%，帯筋体積比は $0.88 \%$ である。

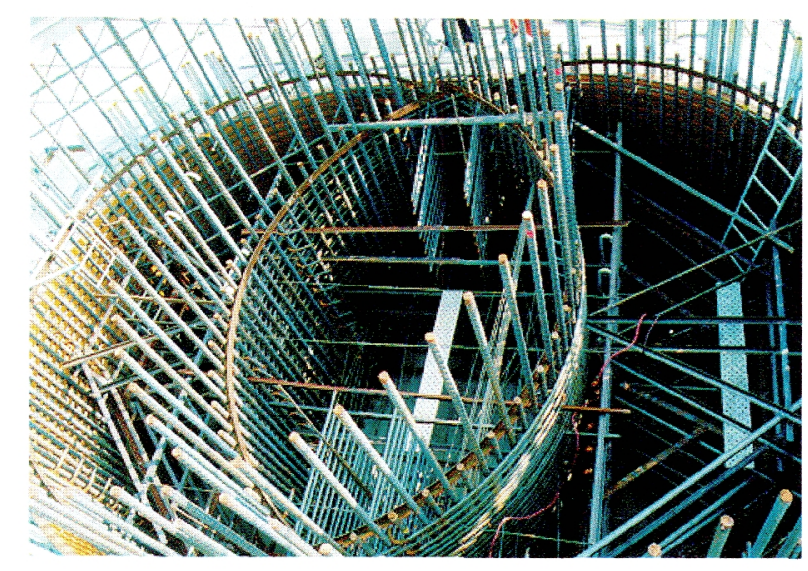

写真-1 中部横断自動車道富士川橋下部工
一方, UNIT 1, 2, 3 は, UNIT0 と同等の曲げ耐力を 有するよう，主鉄筋量を決定したため，主鉄筋比は $1.63 \%$ となった。また，帯筋体積比は，0.19\%，0.29 $\%, 0.52 \%$ の 3 種類とした。なお, 帯筋体積比 $\rho_{s}$ は, 次式により算定した。

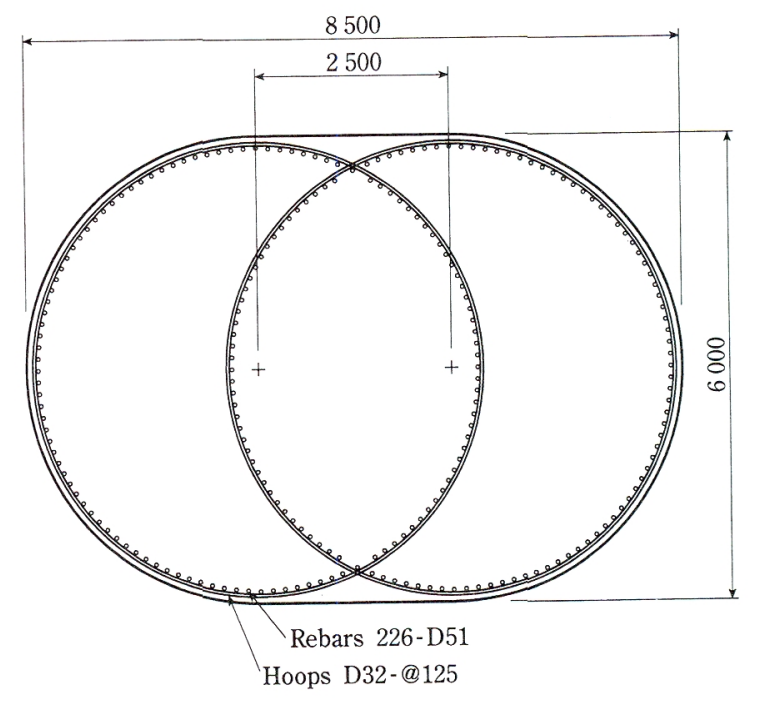

図-4 富士川橋 $P_{4}$ 橋脚

表-2 試験体一覧

\begin{tabular}{|c|c|c|c|c|c|c|c|c|c|c|c|}
\hline \multirow[b]{2}{*}{ Unit } & \multirow[b]{2}{*}{$\begin{array}{l}\text { 断面幅 } \\
\text { (mm) }\end{array}$} & \multirow[b]{2}{*}{$\begin{array}{c}\text { 断面高さ } \\
\text { (mm) }\end{array}$} & \multirow[b]{2}{*}{$\begin{array}{l}\text { せん断 } \\
\text { スパン } \\
(\mathrm{mm})\end{array}$} & \multirow{2}{*}{$\begin{array}{c}\text { コンクリート } \\
\text { 強度 } \\
f_{c} \\
(\mathrm{MPa})\end{array}$} & \multicolumn{3}{|c|}{ 軸方向鉄筋 } & \multicolumn{4}{|c|}{ 横拘束筋 } \\
\hline & & & & & $\begin{array}{l}\text { 本数 } \\
\text { - } \\
\text { 径 }\end{array}$ & $\begin{array}{c}\text { 主筋比 } \\
\rho_{l} \\
(\%)\end{array}$ & $\begin{array}{c}\text { 降伏点 } \\
f_{y l} \\
(\mathrm{MPa})\end{array}$ & 形式 & $\begin{array}{l}\text { 径 } \\
\text { 一 } \\
\text { 間隔 }\end{array}$ & $\begin{array}{c}\text { 体積比* } \\
\rho_{S} \\
(\%)\end{array}$ & $\begin{array}{c}\text { 降伏点 } \\
f_{y l} \\
(\mathrm{MPa})\end{array}$ \\
\hline 0 & 900 & 600 & 3000 & 39.8 & 32-D 16 & 1.18 & 399 & $\begin{array}{c}\text { 矩形フープ+ } \\
\text { 中間帯筋 }\end{array}$ & D 6-@ 80 & 0.88 & 345 \\
\hline 1 & 900 & 600 & 3000 & 28.1 & 38-D 16 & 1.63 & 409 & 円形スパイラル & D 6-@ 120 & 0.19 & 359 \\
\hline 2 & 900 & 600 & 3000 & 39.7 & 38-D 16 & 1.63 & 399 & 円形スパイラル & D 6-@80 & 0.29 & 345 \\
\hline 3 & 900 & 600 & 3000 & 29.2 & 38-D 16 & 1.63 & 409 & 円形スパイラル & D10-@100 & 0.52 & 337 \\
\hline 4 & 600 & 850 & 1620 & 30.9 & $36-\mathrm{D} 13$ & 1.05 & 386 & 円形フープ & D 6-@50 & 0.46 & 364 \\
\hline 5 & 600 & 850 & 1620 & 29.3 & $36-\mathrm{D} 13$ & 1.05 & 386 & 円形フープ & D 6-@100 & 0.23 & 364 \\
\hline 6 & 600 & 850 & 1620 & 31.4 & $36-\mathrm{D} 13$ & 1.05 & 386 & 円形フープ & D6-@ 200 & 0.12 & 364 \\
\hline
\end{tabular}

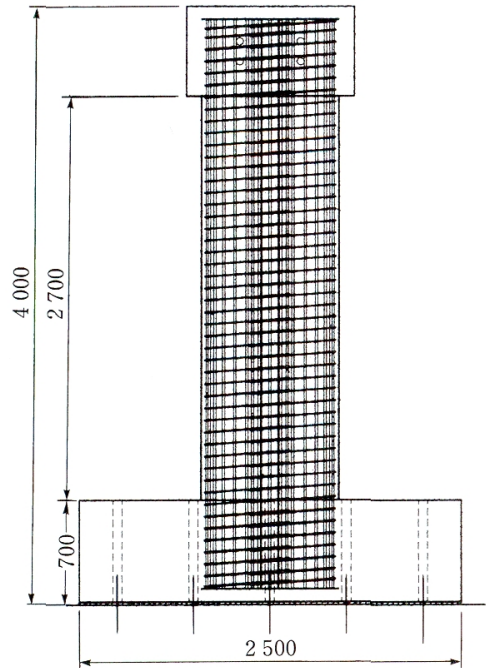

(a) 橋軸方向（UNIT $0 \sim 3$ )
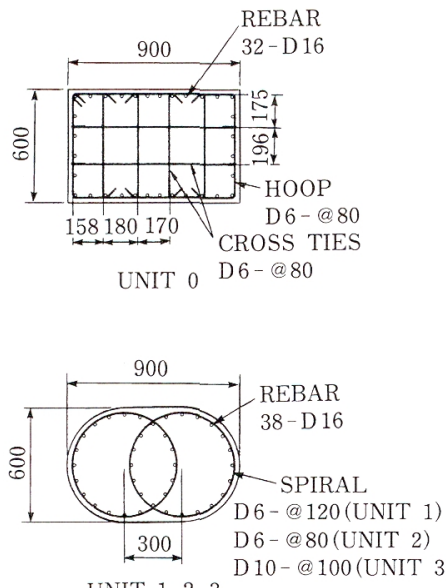

UNIT $1,2,3$

図-5 試験体配筋図
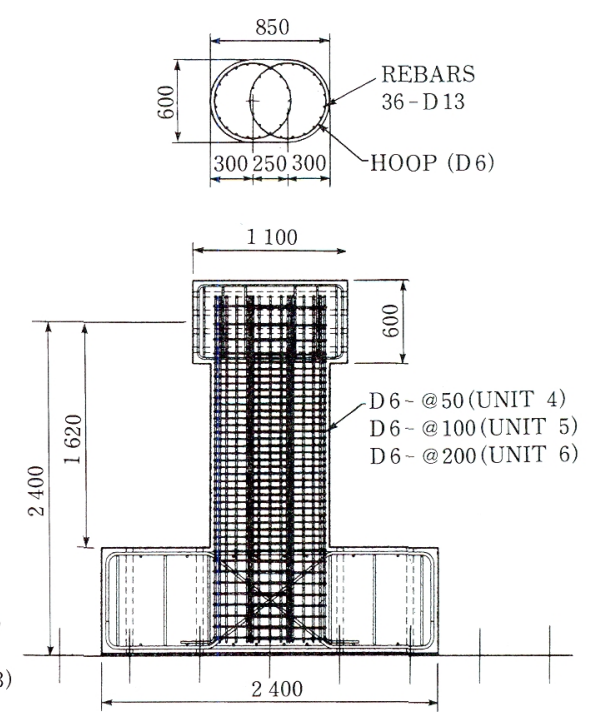

(b) 橋軸直角方向（UNIT 4 6） 


$$
\rho_{s}=\frac{4 A_{h}}{s d}
$$

ここで, $A_{h}$ : 帯鉄筋の断面積 $\left(\mathrm{cm}^{2}\right), s$ : 帯鉄筋の間隔 $(\mathrm{cm}), d$ : 帯鉄筋の有効長 $(\mathrm{cm})$ で, 帯鉄筋や中間帯 鉄筋により分割拘束されるコアコンクリートの辺長のう ち最む長い值。なお，インターロッキング式配筋の有効 長 $d$ として, フープ筋の直径を用いた。

\section{(2) 橋軸直角方向試験体}

表-2 に試験体一覧を, 図-5（b）に試験体配筋図を示 す。試験体（UNIT 4）は富士川橋 $\mathrm{P}_{4}$ 橋脚の約 $1 / 10$ の 諸元をもつ模型として設計し, 主鉄筋比は，1.05\%，帯 筋体積比は $0.46 \%$ である。UNIT 5 および UNIT 6 は, 主鉄筋比が同じで, 帯筋体積比を, それぞれ UNIT 4 の $1 / 2(0.23 \%), 1 / 4(0.12 \%)$ とした。試験体のせん断 スパン比は 1.9 である。

\section{3 実験方法}

載荷方法を図-6に示す。試験体は, PC 鋼棒によって フーチング部を反力床に固定し, 加力スタブに取り付け た $1500 \mathrm{kN}$ アクチュエータによって正負水平交番載荷 した。軸力は, 実橋脚基部断面に生ずる軸圧縮応力度を 想定し, 一定軸力を $\mathrm{PC}$ 鋼棒によって試験体頂部に作用 させた。橋軸方向試験体（UNIT 0 3）および橋軸直角 方向（UNIT 4 6）の軸圧縮応力度は，それぞれ 0.8 $\mathrm{MPa}$ および $1.5 \mathrm{MPa}$ とした。水平力は, 曲げ耐力算定 值の $75 \%$ までは荷重制御によって加力し, 続いて変位

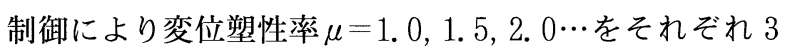
サイクルずつ繰り返した。降伏変位は $75 \%$ 加力時の実 験変位の正負平均値を, 曲げ耐力算定值まで外挿するこ とによって求めた。

測定は, 軸力, 水平力, 試験体水平変位のほか, 主鉄 筋抢よび横拘束筋のひずみを測定した。また，柱の軸方 向変形, 曲率, せん断変形は, 図-6に示すように, 試 験体加力軸線上に設置した変位計と対角に設置した変位 計によって計測した。

\section{4 橋軸方向実験の結果}

\section{(1) 破壊経過}

試験体基部の最終破壊状況および荷重一変形関係を写 真-2, 図-7にそれぞれ示した。また，図-7には，道路 橋示方書に基づく地震動の区分「タイプ II（内陸直下型 の地震動)」に対応する荷重-変形関係の算定值（道示夕 イプП），および最外縁主鉄筋の初降伏時せん断力の算 定値 $V_{y}^{\prime}$ を併せて示した。

UNIT 0 とUNIT 1 3 の最大耐力に至るまでの破壊進 展状況には，顕著な違いは見られなかったが，主鉄筋が 座屈を開始してから終局に至る過程では，以下の違いが 認められた。

-UNIT 0：最外縁の全主鉄笳がほぼ同時に座屈し始め, かぶりコンクリートの剥落に伴って中間帯鉄筋のフッ クが抜け出し，主鉄筋の座屈を拘束しきれずに耐力低 下した。

・UNIT1 3：かぶりコンクリートが剥落し, 最外縁の 主鉄筋が座屈し始めても，スパイラル筋は破断するま で主鉄筋を拘束した。また円形に配置された主鉄筋は, 座屈が最外縁より徐々に進行するため, 主鉄筋の座屈 開始時の繰り返し載荷による耐力低下は UNIT 0 に比 べやや緩やかであり，最終的には，主鉄筋の破断を経 て, 耐力低下に至った。

\section{（2）耐力および変形性能}

各試験体の最大耐力および変形性能を表-3に示した。 これによると，限界変位（図-7 の包絡線が最大耐力の 80\% を下回るときの変位) は, UNIT 0 (188 mm) と UNIT 1，2，3（189，208，192 mm）でほぼ等しく, 実 験結果から算定された塑性率は, 道路橋示方書による算 定值を上回っている。また, UNIT 1 とUNIT 2 では, 帯鉄筋量の違いによる限界変位の增加が認められたが, UNIT 3 では頭打ちとなった。

図-7 の包絡線から, 柱基部より $30 \mathrm{~mm}$ の区間におい て測定した変位から求めた, 主鉄筋の抜け出しによる回

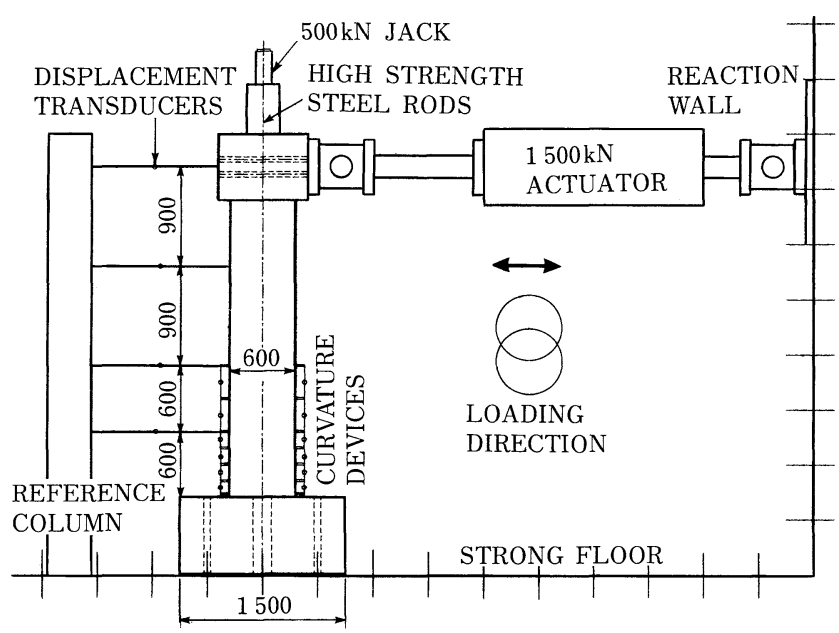

(a) 橋軸方向 (UNIT 0 - 3)

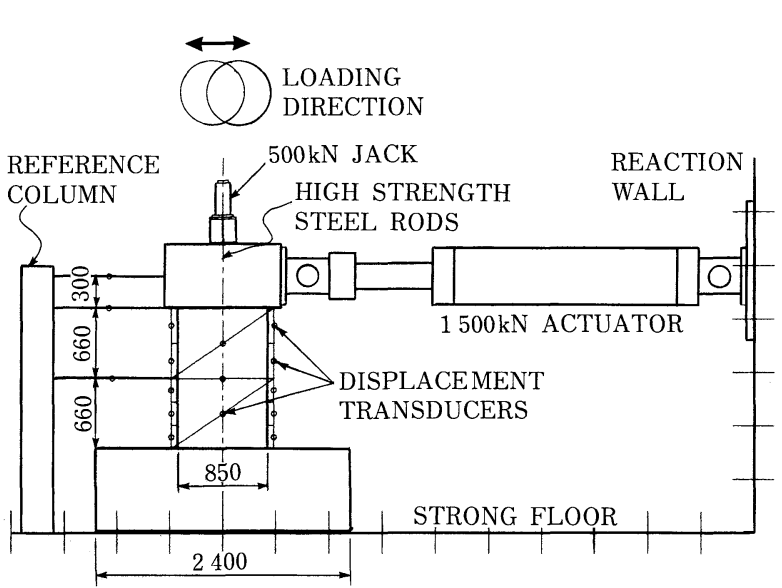

（b）橋軸直角方向（UNIT 4 6） 


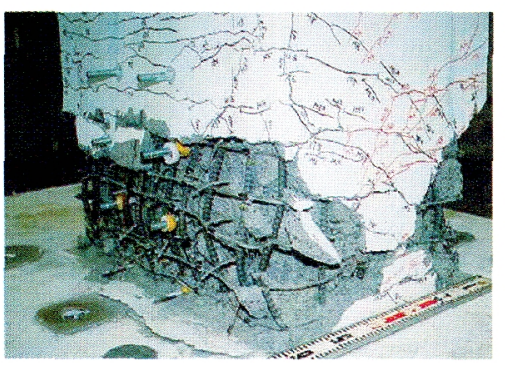

(a) UNIT 0

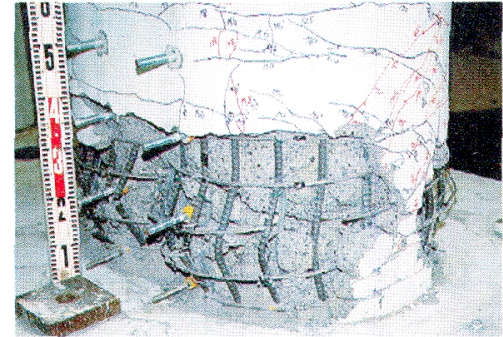

(b) UNIT 2

写真-2 破壊状況

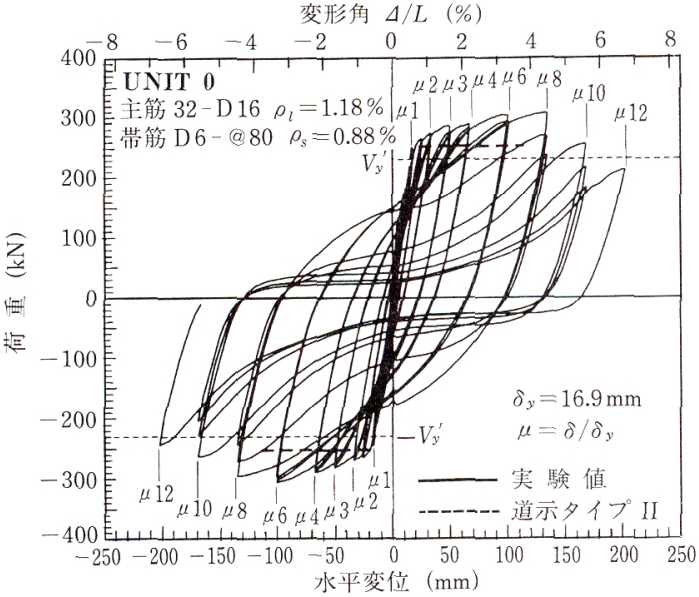

(a) UNIT 0

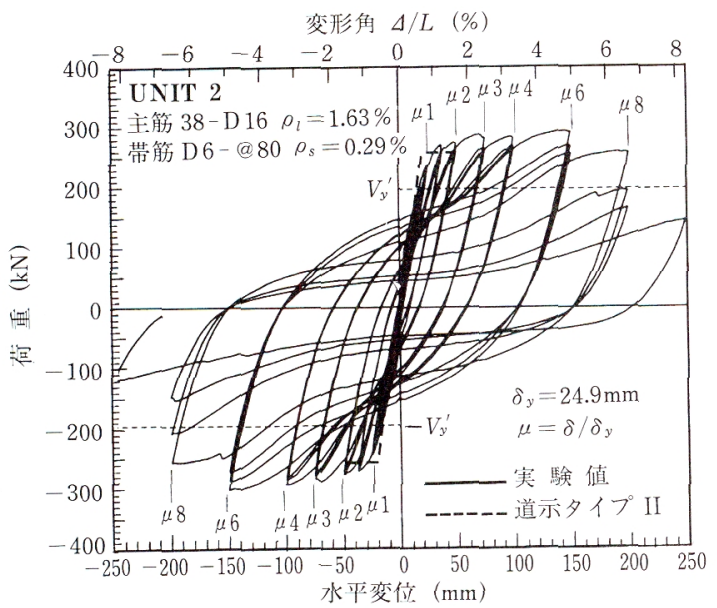

(c) UNIT 2

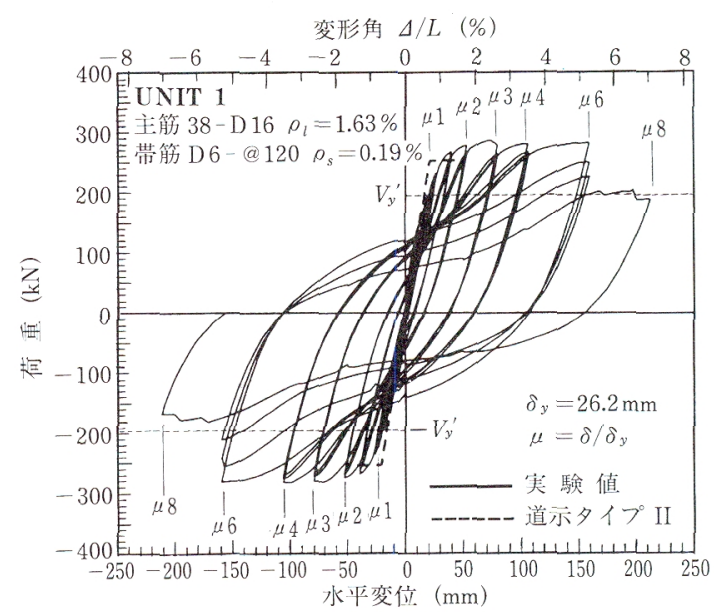

(b) UNIT 1

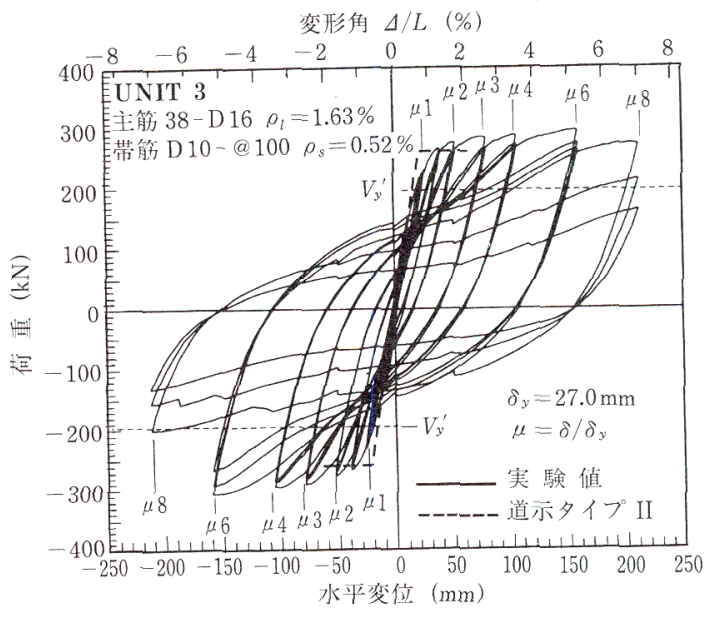

(d) UNIT 3

図-7 荷重-変形関係（橋軸方向実験）

表-3 最大耐力および変形性能

\begin{tabular}{|c|c|c|c|c|c|c|c|c|}
\hline \multirow[b]{2}{*}{ Unit } & \multicolumn{4}{|c|}{ 実験絬果 } & \multicolumn{4}{|c|}{ H 8 道路橋示方書*3 } \\
\hline & $\begin{array}{c}\text { 最大耐力*1 } \\
V_{\max } \\
(\mathrm{kN})\end{array}$ & $\begin{array}{c}\text { 降伏変位 } \\
\delta_{y} \\
(\mathrm{~mm})\end{array}$ & $\begin{array}{c}\text { 限界変位*2 } \\
\delta_{u} \\
(\mathrm{~mm}) \\
\end{array}$ & $\begin{array}{c}\text { 塑性率 } \\
\mu_{\text {exp }} \\
\delta_{u} / \delta_{y}\end{array}$ & $\begin{array}{c}\text { 最大耐力 } \\
V_{\text {max }} \\
(\mathrm{kN})\end{array}$ & $\begin{array}{c}\text { 降伏変位 } \\
\delta_{y} \\
(\mathrm{~mm})\end{array}$ & $\begin{array}{c}\text { 限界変位 } \\
\delta_{u} \\
(\mathrm{~mm})\end{array}$ & $\begin{array}{c}\text { 塑性率 } \\
\mu_{J R A} \\
\delta_{u} / \delta_{y}\end{array}$ \\
\hline 0 & 307 & 16.9 & 188 & 11.1 & 252 & 17.5 & 113.4 & 6.5 \\
\hline $\begin{array}{l}1 \\
2 \\
3\end{array}$ & $\begin{array}{l}283 \\
296 \\
300\end{array}$ & $\begin{array}{l}26.2 \\
24.9 \\
27.0 \\
\end{array}$ & $\begin{array}{l}189 \\
208 \\
192 \\
\end{array}$ & $\begin{array}{l}7.2 \\
8.4 \\
7.1 \\
\end{array}$ & $\begin{array}{l}254 \\
257 \\
261 \\
\end{array}$ & $\begin{array}{l}20.8 \\
20.4 \\
21.8 \\
\end{array}$ & $\begin{array}{l}41.4 \\
46.3 \\
63.1 \\
\end{array}$ & $\begin{array}{l}2.0 \\
2.3 \\
2.9\end{array}$ \\
\hline $\begin{array}{l}4 \\
5 \\
6\end{array}$ & $\begin{array}{l}532 \\
493 \\
529\end{array}$ & $\begin{array}{l}5.7 \\
6.0 \\
5.5\end{array}$ & $\begin{array}{l}68 \\
48 \\
44\end{array}$ & $\begin{array}{r}12.0 \\
8.0 \\
8.0\end{array}$ & $\begin{array}{l}(454) \\
(300) \\
(223)\end{array}$ & $\begin{array}{l}4.08 \\
4.13 \\
4.05\end{array}$ & $\begin{array}{r}15.3 \\
10.2 \\
8.4\end{array}$ & $\begin{array}{l}3.8 \\
2.5 \\
2.1\end{array}$ \\
\hline
\end{tabular}

*1 正負平均值

*2 最大耐力の $80 \%$ を維持できる最大変位

*3 インターロッキングの有効拘束長は，スパイラル・フープ径として算出

UNIT 4 6のせん断耐力は小判形配筋として計算（）は，せ九断破壊型 


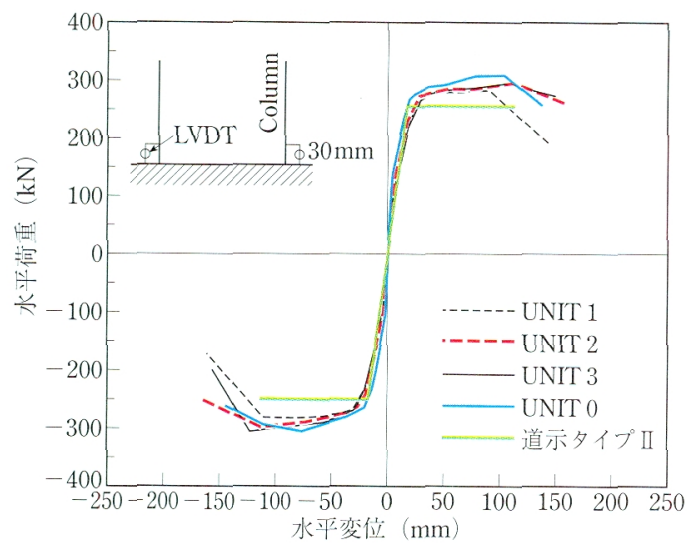

図-8＼cjkstart荷重-変形包絡線

転変位を引いた躯体変形と水平力の関係を図-8に示し た。図中，道路橋示方書の值（道示タイプII）は，表-3 に示したUNIT 0のものである。网-8より, 従来型矩 形橋脚とインターロッキング式橋脚の荷重-変形関係の 包絡線は，耐力低下を生じる点までよく対応しており， 同等の耐震性能を有していると評価できる。

\section{(3) 塑性ヒンジ長}

降伏後の試験体変形が塑性ヒンジの回転によるもの上 仮定すると，試験体変位は，次式で表される。

$$
\delta=\delta_{y}+\left(\phi-\phi_{y}\right) L_{p}\left(h-L_{p} / 2\right)
$$

ここに, $\delta_{y}$ : 降伏変位, $\phi, \phi_{y}$ : 橋脚基部に打ける曲率打 よび降伏曲率, $h$ : 橋脚高さ, $L_{p}$ : 塑性ヒンジ長

（2）式より，塑性ヒンジ長 $L_{p}$ は，次式で表すことが できる。

$$
L_{p}=h-\sqrt{h^{2}-2(\mu-1) \frac{\delta_{y}}{\phi-\phi_{y}}} \quad\left(\mu=\delta / \delta_{y}\right)
$$

実験結果を用いて，（3)式によって算定した各試験体 の $L_{p}$ を図-9に示した。図中, Priestley らの提案式 ${ }^{-12}$ $\left(L_{p}=0.08 h+0.022 f_{y} d_{b l} ; f_{y}\right.$ : 主鉄筋降伏強度, $d_{b l}$ : 主 鉄筋径）および道路橋示方書による $L_{p}$ を示したが，い ずれの試験体も塑性ヒンジ長は,この間で推移しており， これらの式によって，ほぼ妥当に推定できると考えられ る。

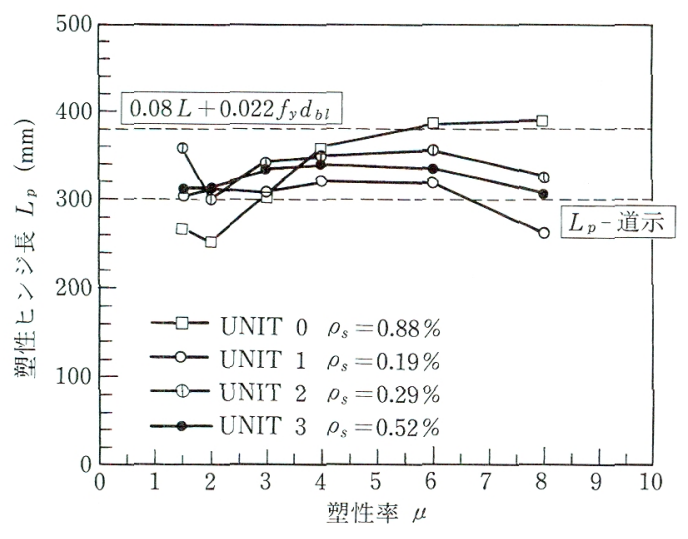

図-9 等価塑性ヒンジ長

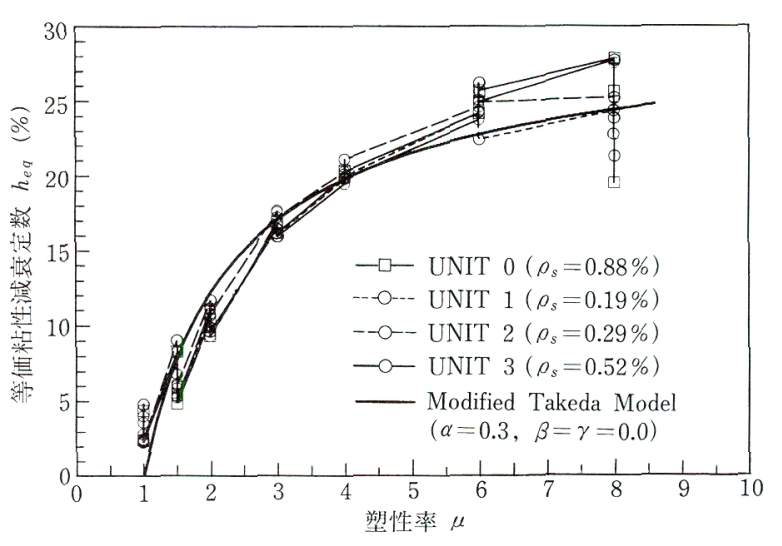

図-10 等価粘性減衰定数

\section{（4）エネルギー吸収能}

図-10に各試験体の荷重-変形関係より求めた等価粘 性減衰定数を示した。これによると, 従来型矩形橋脚お よびインターロッキング式橋朋の同塑性率における等価 粘性減衰定数は, 耐力低下を生じた $\mu=8$ までほぼ一致

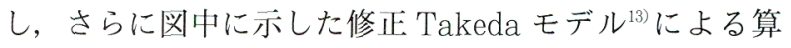
定值之も良い対応を示した。

\section{5 橋軸直角方向の実験結果}

（1）破壊経過および荷重一変位関係

各䪦験体の最終ひび割れ状況と荷重一変形関係を 図-11に示した。また，図中，道路橋示方書に基づく， タイプ II 地震動に対応する保有水平耐力の計算值（道示 タイプII）をバイリニアで示した。いずれの試験体も， 曲げひび割れ，曲げせん断ひび割れ発生後に曲げ降伏し た。UNIT 4, UNIT 5 は，それぞれ変位じん性率 $\mu=12$ および $\mu=8$ にいて主鉄筋の座屈によって耐力低下し， UNIT 6 は $\mu=8$ において, 主鉄筋の座屈を伴うせん断 破壊によって終局となった。

（2）曲げおよびせん断耐力

実験で得られた試験体の最大耐力および道路橋示方書 に基づく保有水平耐力の算定值，道路橋示方書およびコ ンクリート標準示方書によって算定された各試験体のせ ん断耐力を表-4に示した。なお， せん断耐力の算定に あたっては，带鉄筋を小判形配筋として計算した。これ によると, 曲げ耐力の実験值は, 道路橋示方書による保 有水平耐力の算定値をやや上回ったが，十分な精度で曲 げ耐力を推定している。次に道路橋示方書によって算定 したせん断耐力之実験值を比較すると, すべての試験体 で，せん断耐力の算定值が曲げ耐力を下回っている。ま た, 土木学会のせん断耐力式 ${ }^{14)}$ は道路橋示方書より大き なせん断耐力を与えるが，いずれのせん断耐力式におい てもUNIT 5, 6 がせん断破壊先行という結果となった。 一方；実験でせん断破壊したのは，UNIT 6 のみであり， いずれの試験体む，計算值を上回るせん断耐力を有して いたといえる。

\section{（3）変形性能}

実験より得られた各試験体の降伏時変形および終局変 


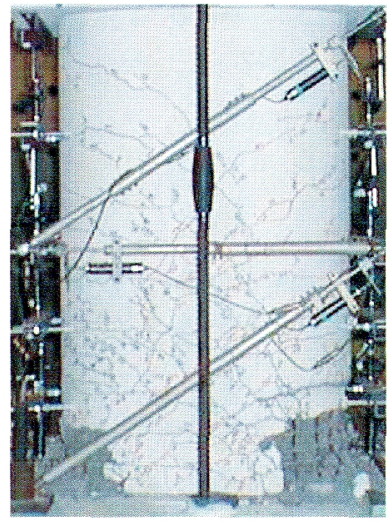

変形角 $\Delta / L(\%)$

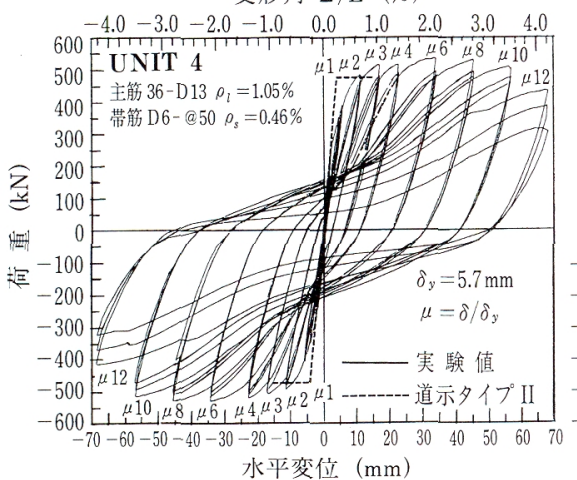

(a) UNIT 4

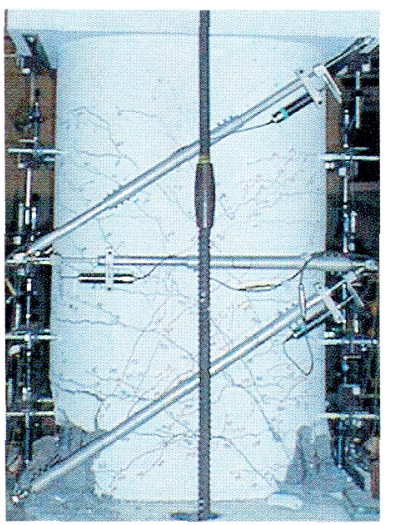

変形角 $\Delta / L \quad \%$

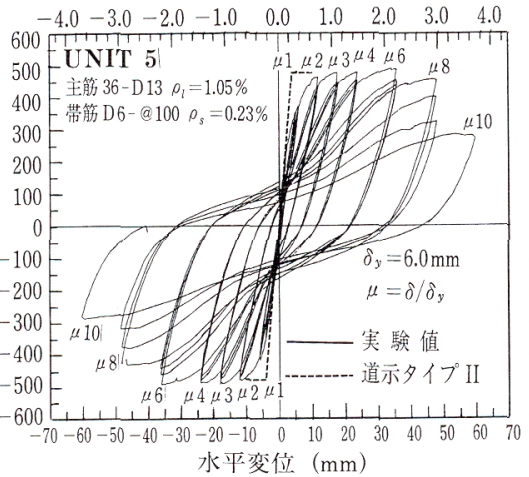

(b) UNIT 5

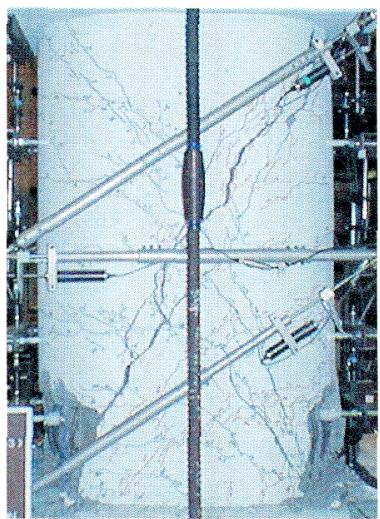

変形角 $\Delta / L(\%)$

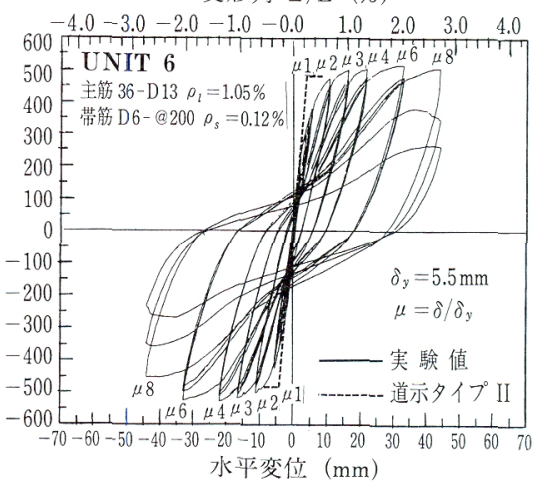

(c) UNIT 6

図-11 破壊状況と荷重-変形関係（橋脚直角方向実験）

表一4 せん断耐力の比較

(単位：kN)

\begin{tabular}{|c|c|c|c|c|c|c|c|}
\hline \multirow[b]{2}{*}{ UNIT } & \multicolumn{2}{|c|}{ 实験值 } & \multicolumn{3}{|c|}{ 道路橋示方書（タイプ II） } & \multicolumn{2}{|c|}{ 上木学会 } \\
\hline & $\begin{array}{c}\text { 最大耐力 } \\
V_{\text {cxp }}\end{array}$ & 破壊形態 & $\begin{array}{c}\text { 曲げ耐力 } \\
V_{u}\end{array}$ & $\begin{array}{c}\text { せん断耐力 } \\
V_{\mathrm{s}}\end{array}$ & 破壊形態 & $\begin{array}{c}\text { せ久断耐力 } \\
V_{s}\end{array}$ & 破壊形態 \\
\hline $\begin{array}{c}4 \\
\left(V_{s} / V_{\text {exp }}\right)\end{array}$ & 532 & 曲げ破塤 & 485 & $\begin{array}{c}454 \\
(0.85)\end{array}$ & せん断破填 & $\begin{array}{c}551 \\
(1.04)\end{array}$ & 曲げ破塤 \\
\hline $\begin{array}{c}5 \\
\left(V_{s} / V_{\text {exp }}\right)\end{array}$ & 493 & 曲げ破壊 & 480 & $\begin{array}{c}300 \\
(0.61)\end{array}$ & せ九断破填 & $\begin{array}{c}394 \\
(0.80)\end{array}$ & せ九断破壊 \\
\hline $\begin{array}{c}6 \\
\left(V_{s} / V_{\text {cxp }}\right)\end{array}$ & 529 & $\begin{array}{c}\text { 曲げ } \rightarrow \\
\text { せん断破壊 }\end{array}$ & 480 & $\begin{array}{c}223 \\
(0.42)\end{array}$ & せん断破壊 & $\begin{array}{c}322 \\
(0.61)\end{array}$ & せん断破填 \\
\hline
\end{tabular}

形とこれらより求めた塑性率を表-3に示した。また， 表には，道路橋示方書より得られた結果も合わせて示し た。終局変形の実験值は, 道路橋示方書による算定値を 大きく上回っている。

また, 実験より得られた各試験体のせん断変形が, 全 体変形に占める割合を図-12に示した。これによると， せん断破壊したUNIT 6 除いて, 加力当初から終局に 至るまで，ほぼ一定（20\% 程度）のせん断変形が計測 された。ただし，せん断補強筋量の小さい順に，せん断 変形の割合が大きくなり，せん断破壊したUNIT 6 にお いては終局時でせん断変形が約 40\%を占めている。

\section{6 耐震性能確認実験のまとめ}

インターロッキング式橋脚のスパイラル筋は，主鉄筋 の座屈防止効果に優れ，带筋体積比が $0.3 \%$ 程度でも， 標準的な矩形配筋構造（帯筋体積比 $0.86 \%$ ）と同等の
耐震性能を発揮した。また，塑性ヒンジ長，エネルギー 吸収性能等は, 既往の計算式で評価できる。しかし, 道 路橋示方書の算定式では，変形性能を小さく評価する可 能性があるため，インターロッキング型配筋の拘束効果 の評価手法, たとえば有効拘束長などについては今後検 討する必要がある。

図-13に，本報告の実験結果と国内外の実験デー 夕 (2 10) から求めた帯筋体積比亡最大塑性率の関係を示し た。これによれば，インターロッキング式橋脚の変形性 能は, 帯筋体積比の増加により改善し, 少なくとも 0.3 \%以上の带筋体積比であれば，じん性能として，塑性 率で 6 程度を確保できると考えられる。

インターロッキング式橋脚のせん断而荷性能は, 従来 の設計方法によって安全側に評価し得る。より合理的な 設計法を考えた場合，インターロッキング領域の配筋状 


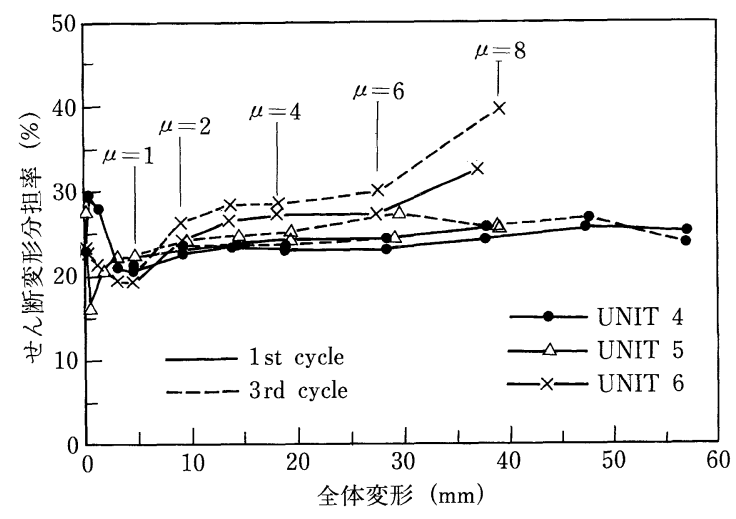

図-12 せん断変形の分担率

態とせん断而荷性能の関係については検討すべき課題で ある。

\section{4. 実大施工実験}

ここでは実大施工実験を例に，インターロッキング式 橋脚をスパイラル筋で施工する方法について紹介する。

\section{1 施工実験の概要}

実験モデルの諸元を図-14 に示す。本モデルでは，あ らかじめコンクリート基礎にネジ節異形鉄筋を配置し, これに機械式継手を用いて主鉄筋を建て込むことで，主 鉄筋量およびその配置形状を任意に変化させることがで きる。また，機械式継手を千鳥に配置して，実施工時に

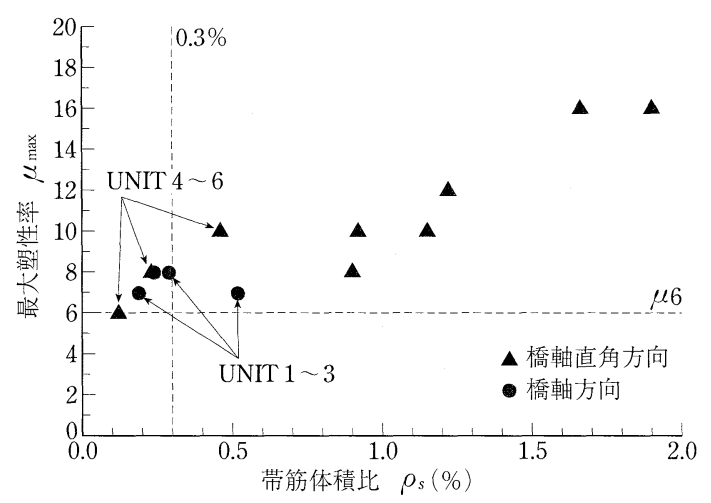

図-13 帯筋体積比と最大塑性率の関係

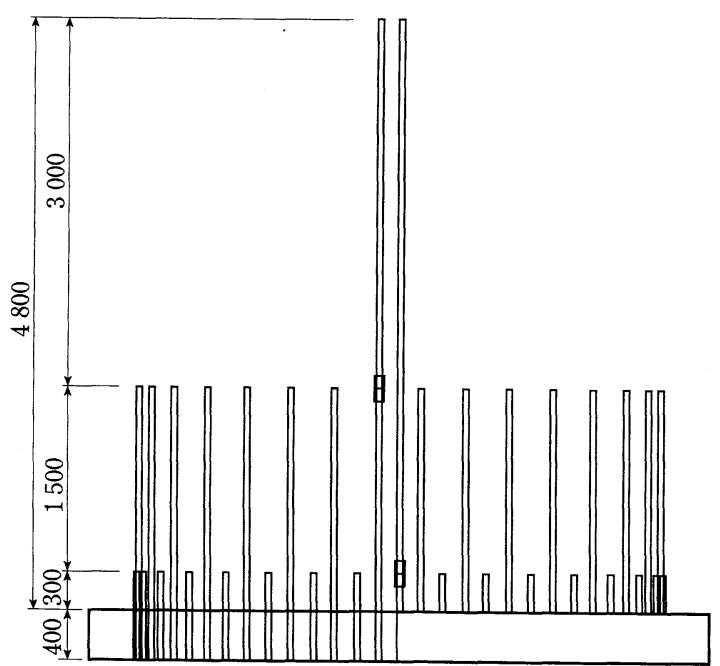

おける主鉄筋の継手位置での施工性の検証も行った。

\section{2 スパイラル筋によるインターロッキング式橋脚} の施工

一連の施工手順を図-15に示す。実施工では，設計寸 法に加工したスパイラル筋を，所定のピッチを保持しな がら円筒形に吊上げ，簡易な治具を使用して重ね合わせ た後, あらかじめ配置された主鉄筋に落とし込む（写 真-3）が，実験ではこれら 1 ロット $(2.7 \mathrm{~m})$ の作業時 間は主鉄筋量にかかわらず約 70 分であった（主鉄筋の 継手作業は除く)。以下にその詳細を示す。

1）スパイラル筋の吊り上げ

スパイラル筋の吊上げ方法を, 図-16 に示す。結束番 線等により，吊りチェーンに固定する方法で，スパイラ ル筋を所定のピッチで吊上げた。また，吊上げ作業を 図-16 に示す組立用ガイドの中で行うと, 容易に所定の 径の円筒形に吊上げることができる（写真-4）。

2） スパイラル筋の重ね合わせ

図-17にスパイラル筋を重ね合わせる際に使用した治 具を示す。この治具により，クレーンの主フックによっ て 2 組のスパイラル筋を吊上げた状態で, 治具中央部の ヒンジを副フックで巻上げることによって， 2 組のスパ イラル筋を容易に重ね合わせることができる。

3）主鉄筋継手部の施工

主鉄筋継手部の施工状況を写真-5，写真-6 に示す。 主鉄筋継手部の施工では, スパイラル筋の落とし込み時 に，スパイラル筋を継手作業に支障のない位置で仮結束 しておき，継手作業完了後，主鉄筋に巻付ける。

\section{3 実大施工実験のまटめ}

施工実験の出来形および施工精度を写真-7, 図-18に 示す。これらは，通常施工の許容範囲内である。

以上，本実験では，簡易な治具を使用することによっ て， スパイラル筋を使用したインターロッキング型配筋 を効率良く施工することが可能であることを確認した。 また，スパイラル筋は，組立後に主鉄筋へ巻付けること によって，その寸法を容易に調整することが可能である

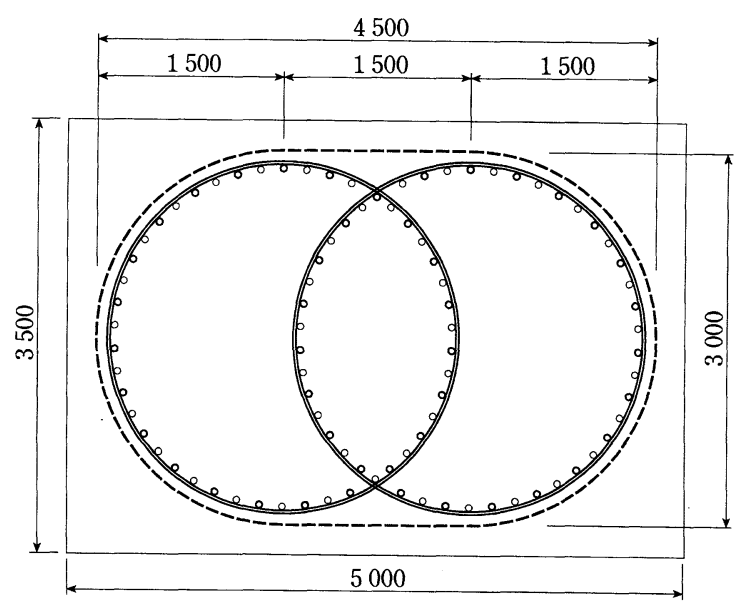

図-14＼cjkstart施工実験モデル 

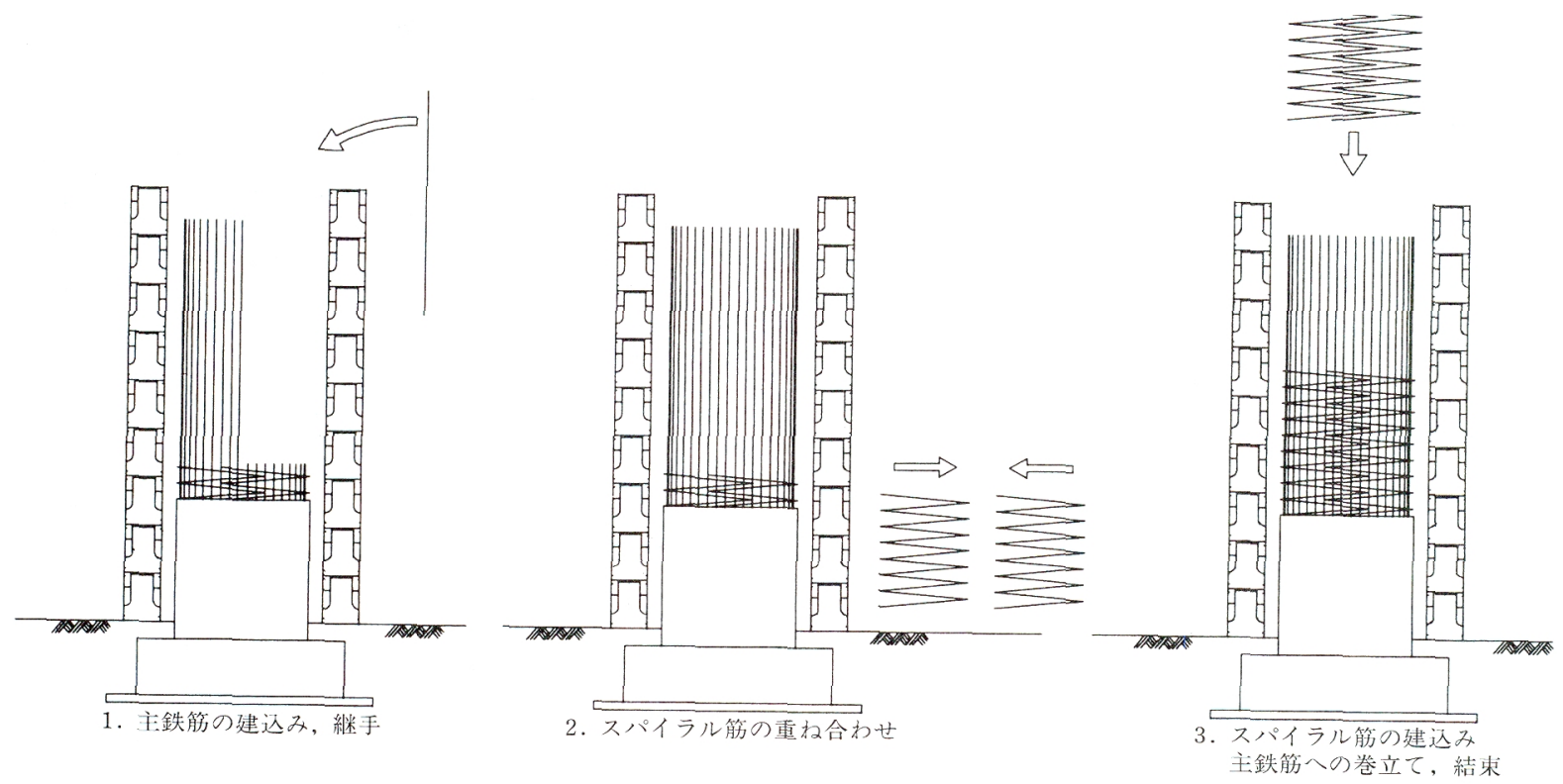

図-15 施工手順

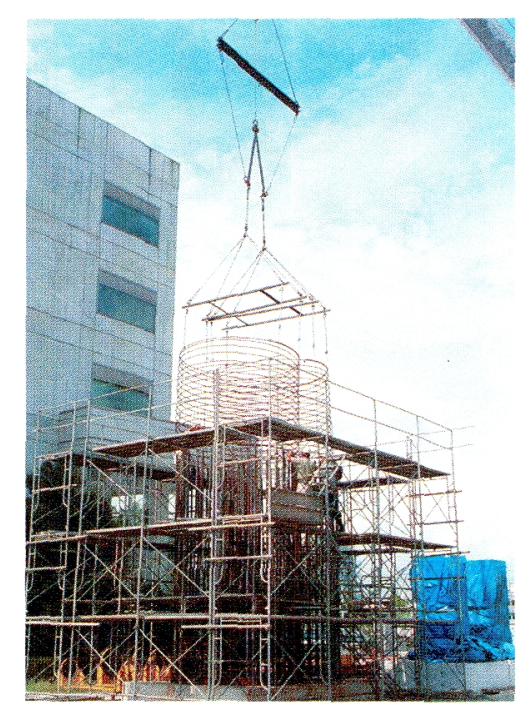

写真-3 スパイラル筋の設置

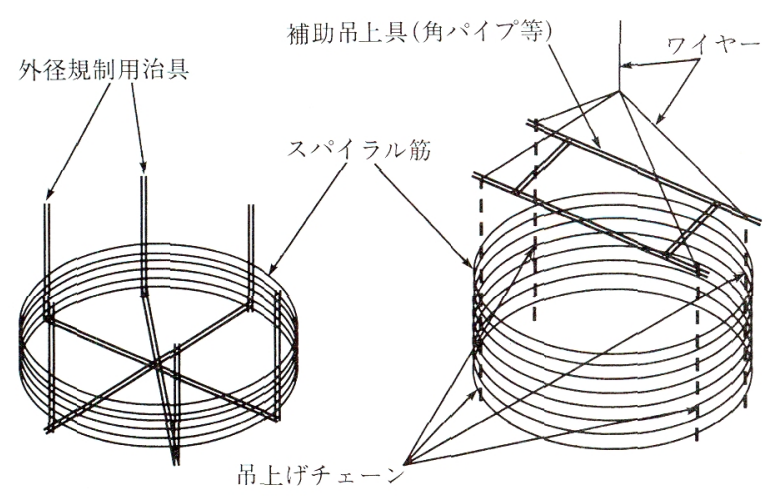

図-16 スパイラル筋の吊上げ方法

ことから，主鉄筋の継手や，組立䛊差の影響を受けず施 工できることがわかった。

5.抒わりに

筆者らが行ったインターロッキング式橋脚に関する研

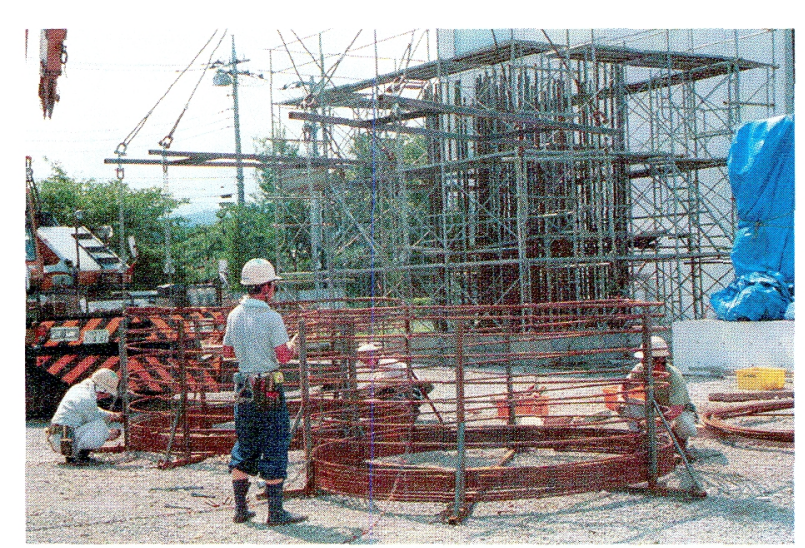

写真-4 スパイラル筋の吊上げ

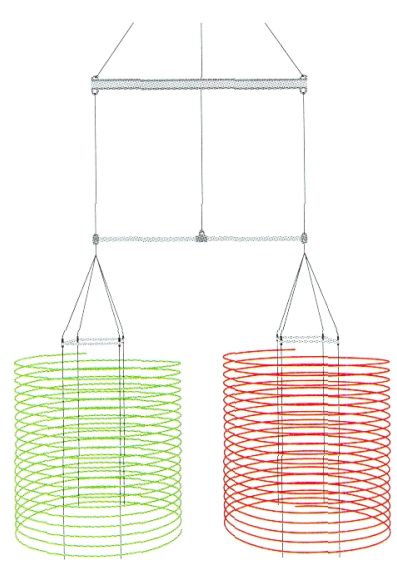

(1)吊上げた状態

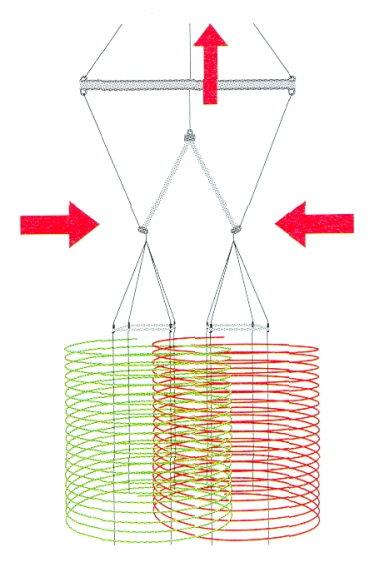

(2)重数合わせた状態
図-17 インターロッキング用吊治具

究を, 簡単に取りまとめて報告した。本稿の内容が、イ ンターロッキング式橋脚を検討する際の参考となれば幸 いである。

1) (社)日本道路協会: 道路橋示力書・同解説 $\mathrm{V}$ 付震設計編, 1996年 


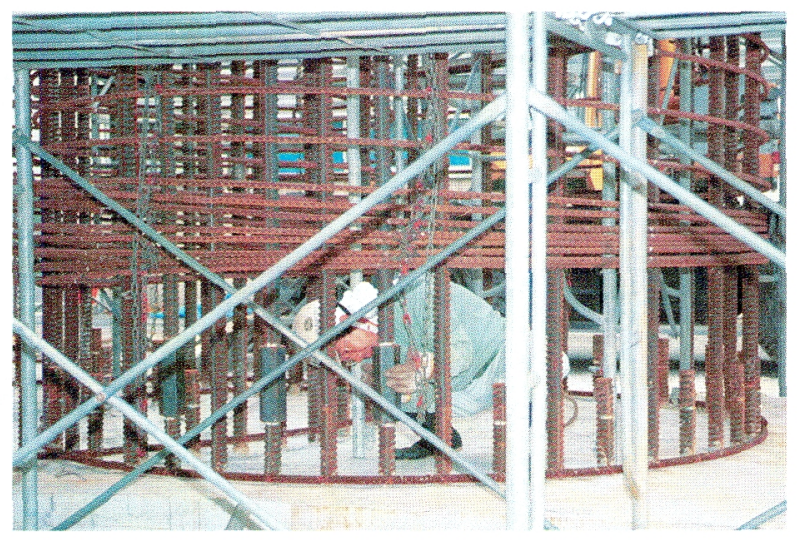

写真 -5 軸方向鉄筋の継手作業

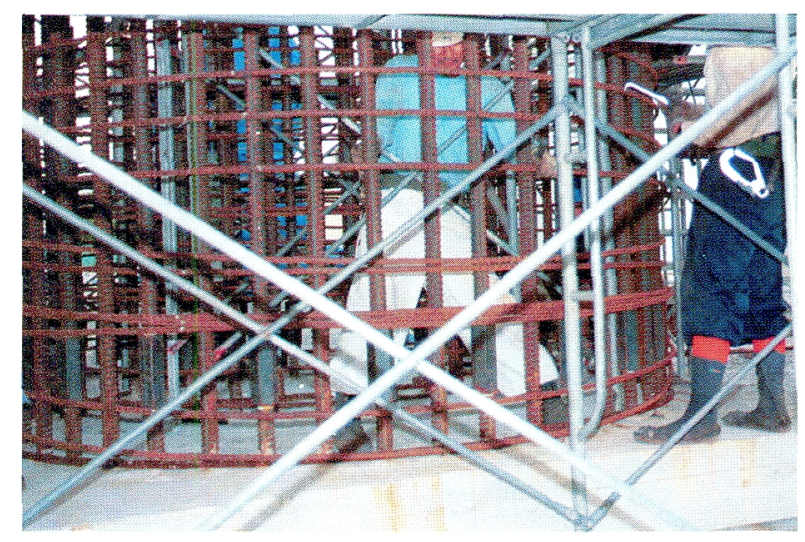

写真-6 スパイラル筋の巻付け
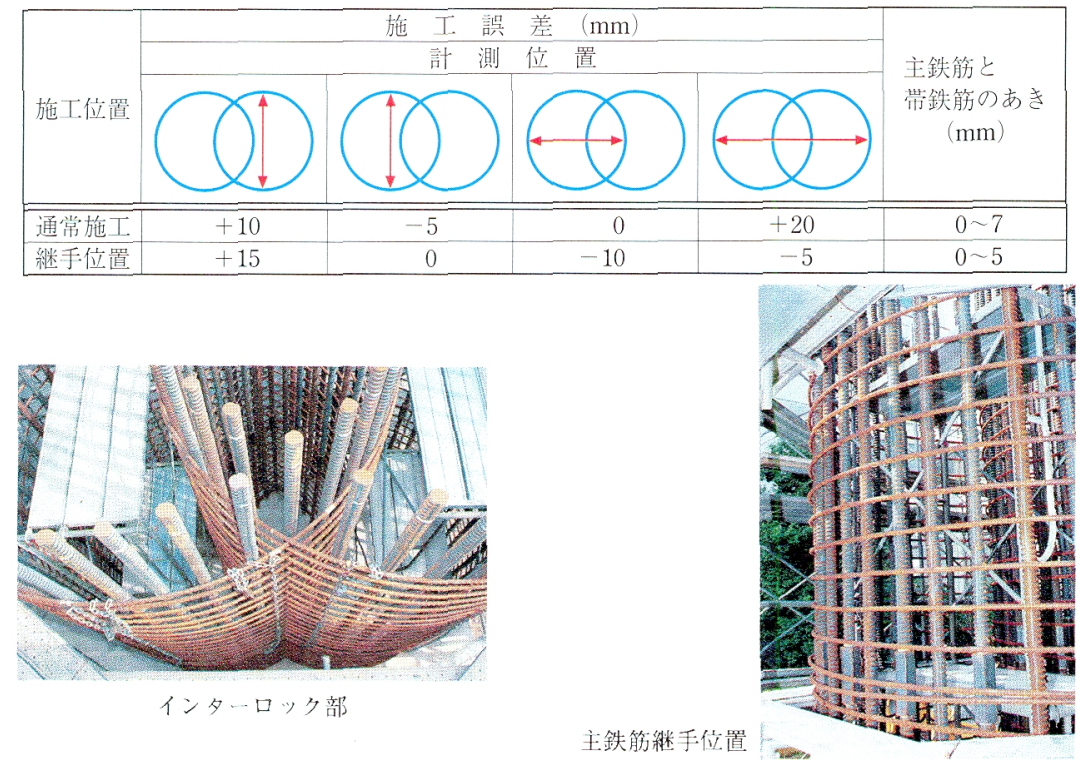

図-18 組立精度

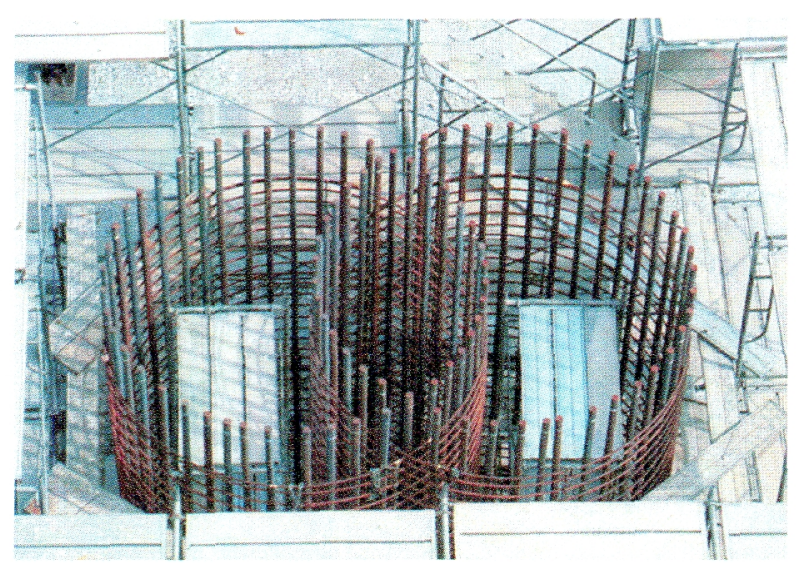

写真-7 組立完了

12 月

2) "CALTRANS Structures Seismic Design References", Bridge Design Specifications, State of California, Department of Transportation January 1993

3）大滰・黑岩・細木：インターロッキング型フーブ筋を有する鉄筋 コンクリート橋却の耐震性能(その1)(その2), 土木学会第53回年 次学術講演会概要集 $\mathrm{V}$, pp.1122 1125, 1998

4）大滝・黑岩：インターロッキング型フーブ筋を有する鉄筋コンク リート橋脚の柎震性能に関する実験的研究, 東急建設技術研究所 報, No. 24, 1998
5）大滝・黑岩・宮城・水上：インターロッキングスパイラル筋を有 する $\mathrm{RC}$ 橋脚の交番載荷実験, コンクリート工学年次論文集, Vol. 22, No. 3, pp. 367 372, 2000

6）黑岩・宮城・大滰・水上：インターロッキングスパイラル配筋に よる $\mathrm{RC}$ 橋扸の合理化工法, コンクリート工学年次論文集, Vol. 23, No. 2, pp. 1279 1284, 2001

7) Tanaka, H., Park, R. : Seismic Design and Behavior of Reinforced Concrete Columns with Interlocking Spirals, ACI Structural Journal, pp. 192-203, March-April 1993

8) Buckingham, G.C. : Seismic Performance of Bridge Columns with Interlocking Spiral Reinforcement, M. S. Thesis, Washington State University, May, 1992

9）柳下・田中・Park, R. : インターロッキングスパイラル鉄筋を有 する鉄筋コンクリート柱の繰り返し荷重下に抒沙る挙動，コンク リート工学年次論文報告集, Vol. 19, No. 2, 1997

10）藤倉・川島・庄司・張・武村：インターロッキング式帯鉄筋を有 する RC 橋脚の耐震性, 土学会論文集, No.640/I-50, pp. 71 88, 2000. 1

11）柳下・田中・Park, R. : インターロッキングスパイラル鉄筋を有 する鉄筋コンクリート橋脚の耐震性能, 土木学会論文集, No. 662 $/ \mathrm{V}-49$, pp. $91 \sim 103,2000.11$

12) Priestley, M. J. N., Seible, F. and Calvi, G. M. : Seismic Design and Retrofit of Bridges, John Wiley \& Sons, Inc, pp. 686, 1996

13) Otani, S. : Inelastic Analysis of R/C Frames Structures, J. Struct, Div., ASCE, 100, ST 7, pp. 1433-1449, 1974

14）紨上木学会：コンクリート標準示方書・耐震設計編, 1996 